\title{
CORRIGENDUM
}

\section{Putting theory to the test: Examining family context, caregiver motivation, and conflict in the Family Check-Up model-CORRIGENDUM}

\author{
GREGORY M. FOSCO, ${ }^{a}$ MARK VAN RYZIN, ${ }^{b}$ ELIZABETH A. STORMSHAK, ${ }^{b}$ AND THOMAS J. DISHION ${ }^{b, c}$ \\ ${ }^{a}$ Pennsylvania State University; ${ }^{b}$ University of Oregon; and ${ }^{c}$ Arizona State University
}

doi:10.1017/S0954579413001004, published by Cambridge University Press, 17 January 2014

Upon subsequent analyses with the same data set, we found that there was a miscalculation in the proportions of families receiving indicated-level services in the Family Check-Up (FCU). The sentence starting on page 308 and ending on page 309 should be the following:

Of the 180 families receiving the FCU, 80\% $(n=131)$ received indicated-level support after feedback. Among families that

\section{Reference}

Fosco, G. M., Van Ryzin, M., Stormshak, E. A., \& Dishion, T. J. (2014). Putting theory to the test: Examining family context, caregiver motivation, received indicated-level support, $36 \%$ received positive behavior support, $71 \%$ (previously reported as 68\%) received support in limit setting and monitoring skills, and $73 \%$ received communication and problem solving support. School-related support was received by $79 \%$ (previously reported as $67 \%$ ).

We regret these errors and any problems they may have caused.

and conflict in the Family Check-Up model. Development and Psychopathology, 26, 305-318. 